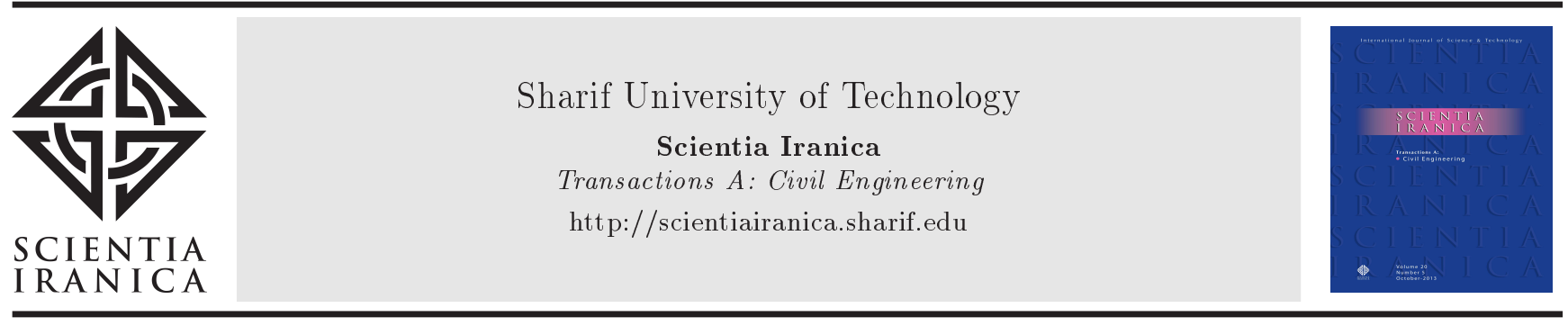

\title{
Research on the risk assessment method of PPP project based on the improved matter element model
}

\author{
B. Liu ${ }^{\mathrm{a}, *}$ and F.H. Sun ${ }^{\mathrm{b}}$ \\ a. Department of Engineering Management, School of Civil Engineering, Nanjing Forestry University, Nanjing, P.R. China. \\ b. Department of Accounting, School of Business, Hohai University, Nanjing, P.R. China.
}

Received 1 October 2017; received in revised form 15 March 2018; accepted 6 August 2018

\author{
KEYWORDS \\ PPP project risk \\ management; \\ Risk assessment; \\ Risk identification; \\ Improved matter \\ element model; \\ Index system.
}

\begin{abstract}
When identifying (Public-Private-Partnership) PPP project risks using the decomposition analysis method, the PPP project risks are considered to include government risk, market risk, and project risk. Based on these facts, a constructed list of PPP project risks is established, which can be divided into three first-class indexes and 27 second-class indexes. Based on the analysis of the traditional matter element model limitations, the evaluation model of PPP project risk assessment of the improved matter element model is established in order to provide effective support for effective PPP project risk management, contract management, and other work. Lastly, the feasibility of theoretical research is verified by a case study.
\end{abstract}

(C) 2020 Sharif University of Technology. All rights reserved.

\section{Introduction}

In the context of China's economy moving into the "new normal," the pressure on public investment resources is rapidly increasing. Since 2013, in order to solve the problem of government/public investment gaps in some areas and to ensure timely construction of public funding projects, the Chinese government has issued a series of relevant policies and encouraged the use of the Public-Private-Partnership (PPP) model in the public sphere.

The PPP model plays an important role in reducing the government's financial burden, enhancing the effectiveness of project implementation, and helping achieve a reasonable distribution of risk. However, in the implementation process, the PPP model has also shown to be subject to numerous problems. This is

\footnotetext{
*. Corresponding author. Fax: +86 02585427955

E-mail addresses: jsgylb@163.com (B. Liu);

fhsun@hhu.edu.cn (F.H.Sun)
}

especially true of risk management. When risk management is not perfect, the entire construction project and operation processes can face many problems, which are manifested in the following forms:

1. Commitments cannot be achieved, thus increasing the credit risk to the Chinese government. The Chinese government lacks enough knowledge and experience in the actual process of attracting foreign investment. To attract investors to these projects, the government has made many commitments. On the one hand, these commitments increase the government's level of risk. On the other hand, these commitments will also inevitably lead to huge government compliance costs [1];

2. The central government's macroeconomic policy adjustments and investment and market intervention can potentially cause projects to fail. Therefore, by using the PPP mode, the level of project risk management should be strengthened. This means that a better job will be done in terms of risk sharing and management. The possibility of risks arising and the cost of any risk caused by losses and 
poor risk management should be reduced in order to give full play to the advantages of the PPP model, thus ensuring that the project runs smoothly [2].

Based on these facts and considering that not too many companies use the PPP model, a number of deficiencies in risk management still exist. Therefore, carrying out the implementation process of PPP project risk management procedures can enhance the efficiency of PPP project risk management and ensure the efficiency of the implementation of the PPP project.

\section{Basic process of PPP project risk assessment}

In the process of implementing PPP project risk assessment, in order to ensure the effectiveness of that risk assessment, carrying out certain processes and steps is necessary. These steps will provide support for the effective development of risk response procedures and practices.

Specifically, when carrying out an assessment of PPP project risk, the basic process is as follows: first, on the basis of risk identification, establish a PPP project risk evaluation index system and ensure the integrity and effectiveness of that index system. Secondly, combine the characteristics of PPP project risk assessment requirements and the risk assessment index system to construct a proper risk assessment model. This can be used in risk assessment to determine the index weight and risk assessment of the implemented policies in order to provide support [3-8]. Finally, through the application of PPP project risk indexes (for characteristic value determination and the risk evaluation model), the size and scale of the PPP project risks become clear.

\section{Establishment of PPP project risk assessment index system}

In the process of carrying out a risk assessment of a PPP project, the most important issue is the construction of a risk assessment index system. The risk assessment index system should be constructed by forming a PPP project risk identification risk list. This list should follow the scientific, system, comparison and operation principles when constructing an index system based on reasonable construction.

We can see the results of PPP project risk identification. The project implementation risks involved in the process are divided into government risk, market risk, and project risk. These are the three main types of risk factors. In addition, all types of risk factors have a specific representation.

Therefore, a PPP project risk assessment index system can be built in the categories of government risk, market risk, and project risk, with the three aspects setting level indicators [9-11]. In addition, we combine the risk identification results and build threelevel indicators of second-class indexes, ultimately forming the formation of the PPP project risk assessment index system.

The PPP project risk assessment index system is shown in Table 1.

According to Table 1, the PPP project risk assessment index system can be divided into three firstclass indexes and 27 second-class indexes, which can more fully reflect the risks of a PPP project.

\section{Establishment of a risk assessment model for a PPP project}

After establishing the PPP project risk evaluation index system, the next problem is the establishment of a PPP project risk assessment model that can be used to quantitatively assess the size of the PPP project's risk and provide effective support [12-14].

In the PPP project risk assessment process, with the help of both theory and method, the key to ensuring effective project risk assessment and effective use of the quantitative assessment method is to use the scientific management method for reference. This can be done by building a risk assessment mathematical model, which will achieve the purposes of the project risk evaluation. The most commonly used methods include the TOPSIS and fuzzy comprehensive evaluation method, the matter element analysis method, and the principal component analysis method. After comparing various methods, this paper attempts to improve the traditional matter element model. Based on our findings, a PPP project risk assessment model is proposed.

\subsection{Limitations of the traditional matter element model}

Matter element analysis was first formulated in the 1980 s as a new discipline. The method is scientific and systematic, using science and mathematics as a crossedge discipline. Through the application of natural science and social science, matter element analysis covers a broad range of cross-disciplines. Matter element analysis is the study of matter elements and how those elements change, as well as the laws and methods used to solve the problem of contradiction. Through matter element analysis, complex images can be examined. Things can be visualized using a multi-index, multi-parameter comprehensive quality evaluation model, eventually leading to the use of the quantitative said evaluation results, which can better reflect the comprehensive level of the quality of things.

We can see that the basic model of matter element is the extension set. Using the matter element transfor- 
Table 1. Index system of Public-Private-Partnership (PPP) project risk assessment.

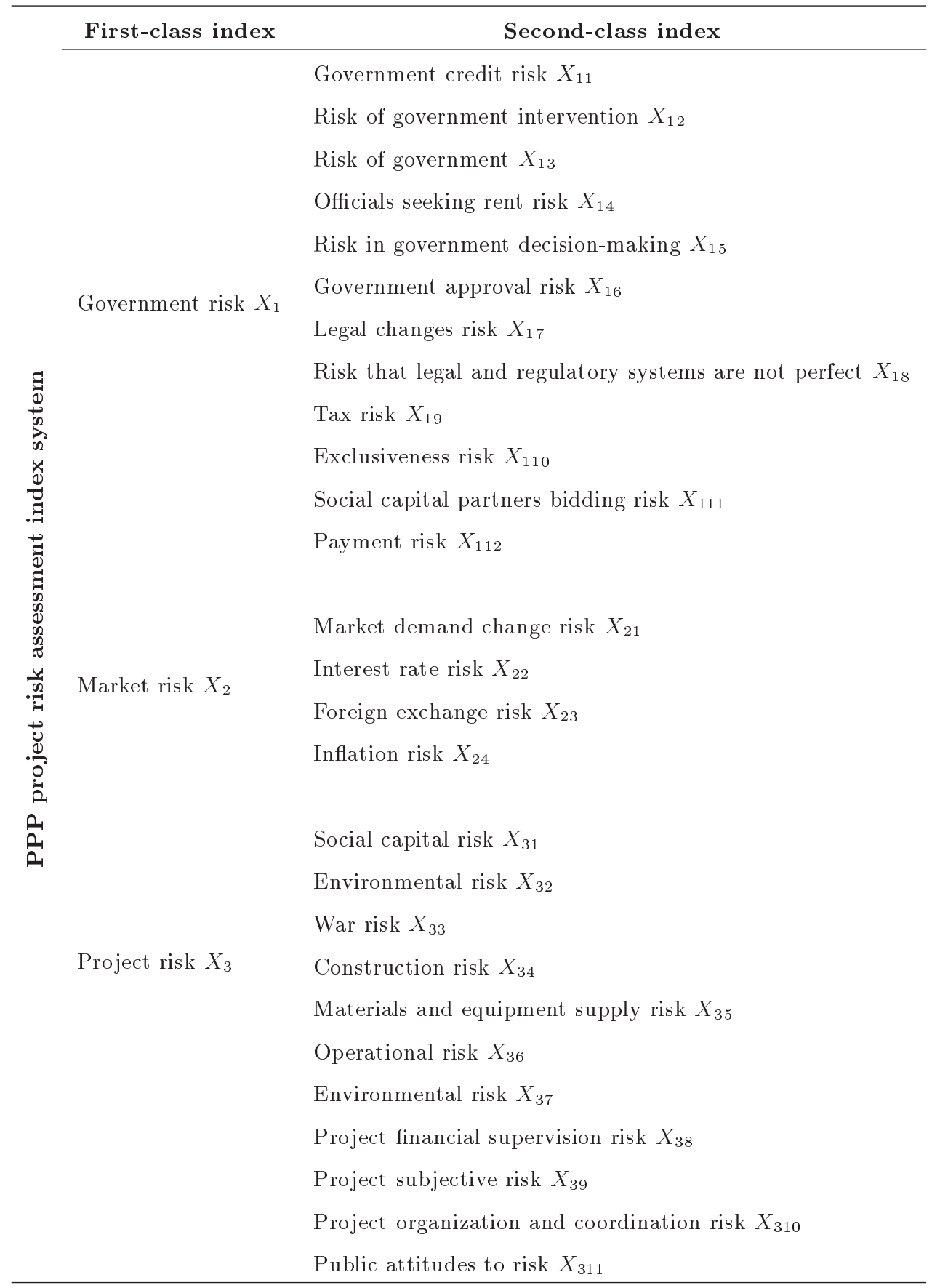

mation method for the non-compatible problem (transformed into compatibility problems) can be a more reasonable way to describe the natural phenomenon, relationships with each other and with the internal structures of the social phenomena in a variety of things, and the changing trends of those things. This is consistent with the purpose and requirements of the PPP project risk assessment.

However, in the traditional matter element model, some limitations exist, specifically in the following two aspects:
1. The determination of the index weight cannot be effectively conducted. This is because the matter element analysis method is mainly used in the processing of numerical analysis. Under the multilevel and multi-index problem of carrying on the discussion, this model cannot determine the index weights. As such, some shortcomings in the handling of the issue will exist;

2. The model cannot deal with multi-person decisions. In the traditional matter element analysis method, 
a multi-person decision-making index eigenvalue processing method is not given. This means that the material element model will face many problems and shortcomings in dealing with multi-person decision-making problems.

\subsection{Establishment of a PPP project risk assessment model based on an improved matter element model}

According to the traditional matter element model, we acknowledge the existence of the limitations of the analysis and, then, establish a PPP project risk assessment model.

The improvements over the traditional matter element model are as follows:

1. For addressing the problem whereby the traditional matter element model cannot effectively carry out the determination of index weights, the Group decision Analytic Hierarchy Process (GAHP) method is introduced. This method provides effective support for the determination of the weight of the PPP project risk assessment index system;

2. For addressing the problem whereby the traditional matter element model cannot deal with the problem of multi-person decision making, a built-indexes decision-making model is constructed. This model is used in conjunction with the matter-element model to facilitate the development of PPP project risk assessment.

Based on the above analysis, the steps used to construct the risk assessment model of a PPP project, based on the improved matter element model, are as follows [15-21]:

Step 1. Determination of weight of the PPP project risk assessment index system. In the process of determining the weight of the risk assessment index system of a PPP project, the weight of $X_{i}$ in the evaluation index system on the effectiveness of the quality management system of manufacturing enterprises is $a_{i}(i=1,2,3)$, first-class index weight vector is $A=\left(a_{1}, a_{2}, a_{3}\right)$ and meets the condition of $a_{i} \geq 0$, and $\sum_{i=1}^{3} a_{i}=1$. The set formed by the weight of second-class indexes $X_{i s}$ to the target layers is $a_{i s}\left(i=1,2,3 ; s=1,2, \cdots, n_{i}\right)$; second-class index weight vector $A_{i}=\left(a_{i 1}, a_{i 2}, \cdots, a_{i n}\right)$. This meets the condition of $a_{i s} \geq 0$ and $\sum_{s=1}^{n_{i}} a_{i s}=1$.

This paper attempts to determine the weight of indexes through the GAHP method, which is an improvement in the traditional AHP method. The basic idea of the GAHP method is to determine the weight of indexes (by experts using AHP). Based on the experts' determination, the arithmetic mean value of the evaluation results is taken as the final result of the PPP project risk assessment index system;

Step 2. Determination of classical domain and domain. In this study, the risks of a PPP project are divided into five levels, namely the highest level, high level, middle level, low level, and lowest level. Correspondingly, PPP project risk assessment indicators are first-class level, second-class level, thirdclass level, fourth-class level, and fifth-class level. The first-class level is the lowest level, second-class is the low level, third-class is the middle level, fourth-class is the high level, and the fifth-class level is the highest level.

The following is the classical domain $\left(R_{0 j}\right)$ of each level under the index of government risk $\left(X_{1}\right)$.

$$
R_{01}=\left[\begin{array}{ccc}
\text { first-level } & X_{11} & 0-20 \\
& X_{12} & 0-20 \\
& X_{13} & 0-20 \\
X_{14} & 0-20 \\
X_{15} & 0-20 \\
X_{16} & 0-20 \\
X_{17} & 0-20 \\
X_{18} & 0-20 \\
X_{19} & 0-20 \\
X_{110} & 0-20 \\
X_{111} & 0-20 \\
X_{112} & 0-20
\end{array}\right],
$$$$
R_{02}=\left[\begin{array}{ccc}
\text { second-level } & X_{11} & 20-40 \\
& X_{12} & 20-40 \\
& X_{13} & 20-40 \\
& X_{14} & 20-40 \\
& X_{15} & 20-40 \\
X_{16} & 20-40 \\
X_{17} & 20-40 \\
X_{18} & 20-40 \\
X_{19} & 20-40 \\
X_{110} & 20-40 \\
X_{111} & 20-40 \\
X_{112} & 20-40
\end{array}\right]
$$$$
R_{03}=\left[\begin{array}{ccc}
\text { third-level } & X_{11} & 40-60 \\
& X_{12} & 40-60 \\
& X_{13} & 40-60 \\
& X_{14} & 40-60 \\
& X_{15} & 40-60 \\
& X_{16} & 40-60 \\
& X_{17} & 40-60 \\
& X_{18} & 40-60 \\
X_{19} & 40-60 \\
X_{110} & 40-60 \\
& X_{111} & 40-60 \\
& X_{112} & 40-60
\end{array}\right]
$$ 


$$
R_{04}=\left[\begin{array}{ccc}
\text { fourth-level } & X_{11} & 60-80 \\
& X_{12} & 60-80 \\
& X_{13} & 60-80 \\
& X_{14} & 60-80 \\
& X_{15} & 60-80 \\
& X_{16} & 60-80 \\
& X_{17} & 60-80 \\
X_{18} & 60-80 \\
X_{19} & 60-80 \\
X_{110} & 60-80 \\
X_{111} & 60-80 \\
X_{112} & 60-80
\end{array}\right],
$$

$$
R_{05}=\left[\begin{array}{ccc}
\text { fifth-level } & X_{11} & 80-100 \\
& X_{12} & 80-100 \\
X_{13} & 80-100 \\
X_{14} & 80-100 \\
X_{15} & 80-100 \\
X_{16} & 80-100 \\
X_{17} & 80-100 \\
X_{18} & 80-100 \\
X_{19} & 80-100 \\
X_{110} & 80-100 \\
X_{11} & 80-100 \\
X_{112} & 80-100
\end{array}\right] .
$$

Domain $R_{p 1}=[($ government risk $)]$ :

$$
R_{p 1}=\left[\begin{array}{ll}
X_{11} & 0-100 \\
X_{12} & 0-100 \\
X_{13} & 0-100 \\
X_{14} & 0-100 \\
X_{15} & 0-100 \\
X_{16} & 0-100 \\
X_{17} & 0-100 \\
X_{18} & 0-100 \\
X_{19} & 0-100 \\
X_{110} & 0-100 \\
X_{111} & 0-100 \\
X_{112} & 0-100
\end{array}\right]
$$

Other indicators' classical domain of each level is similar to the above;

Step 3. Determination of non-evaluated matter element. The risk assessment party invited a number of experts to evaluate various types of risk rating model water conservancy projects and record the value $\left(x_{i n}\right)$ of each indicator. Non-evaluated matter element $(m)$ is four in the process of PPP project risk assessment. It is assumed here that the object to be evaluated is $P_{m}(m=0,1, \cdots, 3)$, and the nonevaluated matter element is $R_{m}$.

The following is the non-evaluated matter element of PPP project risk assessment:

$$
\left.\begin{array}{rl}
R_{1} & =\left[\begin{array}{lll}
p_{1} & X_{11} & x_{11} \\
& X_{12} & x_{12} \\
& X_{13} & x_{13} \\
X_{14} & x_{14} \\
X_{15} & x_{15} \\
X_{16} & x_{16} \\
X_{17} & x_{17} \\
X_{18} & x_{18} \\
X_{19} & x_{19} \\
X_{110} & x_{110} \\
X_{111} & x_{111} \\
X_{112} & x_{112}
\end{array}\right], \quad R_{2}=\left[\begin{array}{lll}
p_{2} & X_{21} & x_{21} \\
X_{22} & x_{22} \\
X_{23} & x_{23} \\
X_{24} & x_{24}
\end{array}\right], \\
X_{31} & x_{31} \\
X_{32} & x_{32} \\
X_{33} & x_{33} \\
X_{34} & x_{34} \\
X_{35} & x_{35} \\
X_{36} & x_{36} \\
X_{37} & x_{37} \\
X_{38} & x_{38} \\
X_{39} & x_{39} \\
X_{310} & x_{310} \\
X_{311} & x_{311}
\end{array}\right], \quad R_{0}=\left[\begin{array}{lll}
p_{0} & X_{1} & x_{1} \\
& X_{2} & x_{2} \\
p_{3} & x_{3}
\end{array}\right],
$$

where:

$R_{0} \quad$ The matter element of PPP project risk;

$R_{1} \quad$ The matter element of government risk in PPP project risk;

$R_{2} \quad$ The matter element of market risk in PPP project risk;

$R_{3} \quad$ The matter element of project risk in PPP project risk;

$x_{i} \quad$ The weighted value of the first-level risk index, $i=1,2,3$

The specific method to determine the value $\left(x_{i n}\right)$ of each indicator is as follows.

Different experts have different understandings of PPP project risk assessment indexes and different interval values of the second-class index. Assuming that there are a total of $K$ experts participating in the evaluation of PPP project risk assessment indexes, $K$ expert gives an interval value $\left[v_{1 p}^{(k)}, v_{2 p}^{(k)}\right]$ set to a second-class index $\left(k=1,2, \cdots, K ; v_{2 p}^{(k)} \geq v_{1 p}^{(k)}\right)$. Then:

$$
x_{i n}=\frac{1}{2} \sum_{k=1}^{K}\left[\left(v_{2 p}^{(k)}\right)^{2}-\left(v_{1 p}^{(k)}\right)^{2}\right] / \sum_{k=1}^{K}\left[v_{2 p}^{(k)}-v_{1 p}^{(k)}\right] .
$$

Step 4. Determination of correlation degree of each index ( $j$ ) and the matter element to be evaluated. Suppose: 


$$
K_{j}\left(x_{i}\right)=\left\{\begin{array}{c}
\frac{\rho\left(x_{i}, x_{0 j i}\right)}{\rho\left(x_{i} x_{p^{i}}\right)-\rho\left(x_{i}, x_{0 j i}\right)}, \\
\rho\left(x_{i}, x_{p_{i}}\right)-\rho\left(x_{i}, x_{0 j i}\right) \neq 0 \\
-\rho\left(x_{i}, x_{0 j i}\right)-1, \\
\rho\left(x_{i}, x_{p i}\right)-\rho\left(x_{i}, x_{0 j i}\right)=0
\end{array}\right.
$$

where:

$$
\begin{aligned}
\rho\left(x_{i}, x_{0 j i}\right)= & \left|x_{i}-\frac{1}{2}\left(a_{0 j i}+b_{0 j i}\right)\right| \\
& -\frac{1}{2}\left(b_{0 j i}-a_{0 j i}\right), \\
\rho\left(x_{i}, x_{p i}\right)= & \left|x_{i}-\frac{1}{2}\left(a_{p i}+b_{p i}\right)\right| \\
& -\frac{1}{2}\left(b_{p i}-a_{p i}\right),
\end{aligned}
$$

where:

$$
\begin{array}{ll}
b_{0 j i} & \begin{array}{l}
\text { The upper bound of the classical } \\
\text { domain; }
\end{array} \\
a_{0 j i} & \text { The lower bound of the classical } \\
& \text { domain; } \\
b_{p i} & \text { The upper bound of the domain; } \\
a_{p i} & \text { The lower bound of the domain; } \\
\rho\left(x_{i}, x_{0 j i}\right) & \begin{array}{l}
\text { The distance between point } x_{i} \text { and } \\
\text { interval } x_{0 j i} \text {; }
\end{array} \\
\rho\left(x_{i}, x_{p i}\right) & \begin{array}{l}
\text { The distance between point } x_{i} \text { and } \\
\text { interval } x_{p i} .
\end{array}
\end{array}
$$

Step 5. Calculating the correlation degree between things to be evaluated $P_{m}$ and each level $j$. If the weight coefficient of the index $X_{i}$ is $a_{i}$ and $\sum_{i=1}^{n} a_{i}=$ 1, then:

$$
K_{j}(p)=\sum_{i=1}^{n} a_{i} K_{j}\left(x_{i}\right) .
$$

In the above formula, $K_{j}(p)$ is the combined value of the correlation degree of every index of the things to be evaluated. This formula is not only the model used to evaluate the degree $j$ of relevance, but also the model that is used to calculate the relationship between the things to be evaluated and the evaluation degree $j$;

Step 6. Rating. If $K_{j_{0}}(p)=\max _{j \in(1,2, \cdots, m)} K_{j}(p), P_{m}$ is rated as grade $P_{m}$.

Based on the above analysis, a PPP project risk assessment model that is based on the improved matter element model can effectively assess the overall level of PPP project risk and also separately calculate the levels of government risk, market risk, and project risk, thus providing effective support for the development of a risk response strategy.

\section{Case analysis: A case study of the He Qiang An (HQA) water source protection project}

\subsection{Overview of the $H Q A$ water conservation project}

The HQA water conservation project referred to in this study is located in "A" province. Working on the assumption that the implementation of the project involves the issue of water resources protection and the right to use water resources, the water resources administrative departments involved in this project decided to use the PPP model to run the project. The water resources administrative departments chose the project's Social Capital Partners- B Company. The administrative departments used open bidding to set up an item company in accordance with the relevant laws. Government departments (through the franchise agreement) agreed to grant the Item Company financing, construction, and rights of operation.

In order to effectively conduct the necessary contract negotiations, a provincial water resources administrative department entrusted "C" advisory body to analyze the HQA water source protection project with regard to the implementation of a risk response strategy. The advisory body ensures the level of risk is maintained and provides effective support for the development of a risk response strategy.

\subsection{Implementation of risk assessment for $H Q A$ water source protection project}

The "C" advisory body organization has 11 experts, who participate in the implementation of the HQA water source protection project risk assessment. The detailed information about the seven experts is shown in Table 2.

The specific risk assessment procedures are as follows:

Step 1. Determine an index system and a weight of index system of the HQA water source protection project risk assessment. Experts agreed to use Table 1 in the PPP project risk assessment index system as the HQA water source protection project risk assessment index system. They also used the GAHP method to determine the weight of indexes through GAHP. The basic idea of this method is to determine the respective weight of indexes, which is conducted by experts using AHP. Based on the findings, the arithmetic mean value of the expert evaluation results is taken as the final result.

The results of the weights of the HQA water resources protection project risk assessment index system are shown in Table 3 ;

Step 2. Determination on the value of the risk assessment index of the HQA water source protection project. Eleven experts determined the value of the risk assessment index of the HQA water source pro- 
Table 2. Detailed information of the eleven experts.

\begin{tabular}{|c|c|c|c|c|}
\hline Surname & Title & Work unit & Qualification & Expertise \\
\hline $\mathrm{Xu}$ & Vice Professor & Hohai University & Consulting engineer & Project management \\
\hline Zhang & Senior engineer & $\begin{array}{l}\text { Guangdong Research Institute of } \\
\text { Water Resources and Hydropower }\end{array}$ & $\begin{array}{l}\text { Consulting engineer; } \\
\text { Cost engineer }\end{array}$ & Project financing \\
\hline $\mathrm{Bu}$ & Professor & Yangzhou University & Cost engineer & Project financing \\
\hline Wang & Professor & Hohai University & Consulting engineer & Project risk management \\
\hline Jian & Senior engineer & $\begin{array}{l}\text { Water Conservancy Bureau of } \\
\text { Guangdong Province }\end{array}$ & Cost engineer & Project management \\
\hline $\mathrm{Li}$ & Senior engineer & $\begin{array}{l}\text { Water Conservancy Bureau of } \\
\text { Guangdong Province }\end{array}$ & Consulting engineer & $\begin{array}{l}\text { Construction technology of } \\
\text { water conservancy project }\end{array}$ \\
\hline Wang & Senior engineer & $\begin{array}{l}\text { Water Conservancy Bureau of } \\
\text { Guangdong Province }\end{array}$ & $\begin{array}{l}\text { Consulting engineer; } \\
\text { Cost engineer }\end{array}$ & $\begin{array}{l}\text { Construction technology of } \\
\text { water conservancy project }\end{array}$ \\
\hline Jin & Senior engineer & $\begin{array}{l}\text { Water Conservancy Bureau } \\
\text { of Jiangsu Province }\end{array}$ & $\begin{array}{l}\text { Guangdong Hydropower } \\
\text { Planning and Design } \\
\text { Institute }\end{array}$ & Project management \\
\hline Liu & Senior engineer & $\begin{array}{l}\text { Engineering Consulting Center } \\
\text { of Guangdong Province }\end{array}$ & Consulting engineer & $\begin{array}{l}\text { Construction technology of } \\
\text { water conservancy project }\end{array}$ \\
\hline Shen & Professor & $\begin{array}{l}\text { Nanjing Hydraulic Research } \\
\text { Institute }\end{array}$ & Consulting engineer & Project risk management \\
\hline $\mathrm{He}$ & Senior engineer & $\begin{array}{l}\text { Pearl River water resources } \\
\text { commission of the ministry } \\
\text { of water resources }\end{array}$ & $\begin{array}{l}\text { Consulting engineer; } \\
\text { Cost engineer }\end{array}$ & Project financing \\
\hline
\end{tabular}

Table 3. Weights of the He Qiang An (HQA) water resources protection project risk assessment index system.

\begin{tabular}{|c|c|c|c|}
\hline & First-class index & Second-class index & $\begin{array}{l}\text { Second-class index } \\
\text { relative to the } \\
\text { target layer weights }\end{array}$ \\
\hline 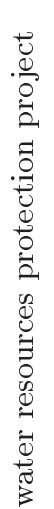 & Government risk $X_{1}$ & $\begin{array}{l}\text { Government credit risk } X_{11} \\
\text { Risk of government intervention } X_{12} \\
\text { Risk of socialization } X_{13} \\
\text { Officials seeking rent risk } X_{14} \\
\text { Risk in government decision-making } X_{15} \\
\text { Government approval risk } X_{16} \\
\text { Legal changes risk } X_{17} \\
\text { Risk that legal and regulatory systems are not perfect } X_{18} \\
\text { Tax risk } X_{19} \\
\text { Exclusiveness risk } X_{110} \\
\text { Social capital partners bidding risk } X_{111} \\
\text { Payment risk } X_{112}\end{array}$ & $\begin{array}{l}0.042 \\
0.039 \\
0.033 \\
0.041 \\
0.037 \\
0.044 \\
0.030 \\
0.044 \\
0.040 \\
0.027 \\
0.044 \\
0.030\end{array}$ \\
\hline 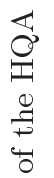 & Market risk $X_{2}$ & $\begin{array}{l}\text { Market demand change risk } X_{21} \\
\text { Interest rate risk } X_{22} \\
\text { Foreign exchange risk } X_{23} \\
\text { Inflation risk } X_{24}\end{array}$ & $\begin{array}{l}0.062 \\
0.039 \\
0.020 \\
0.055\end{array}$ \\
\hline 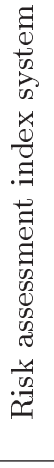 & Project risk $X_{3}$ & $\begin{array}{l}\text { Social capital risk } X_{31} \\
\text { Environmental risk } X_{32} \\
\text { War risk } X_{33} \\
\text { Construction risk } X_{34} \\
\text { Materials and equipment supply risk } X_{35} \\
\text { Operational risk } X_{36} \\
\text { Environmental risk } X_{37} \\
\text { Project financial supervision risk } X_{38} \\
\text { Project subjective risk } X_{39} \\
\text { Project organization and coordination risk } X_{310} \\
\text { Public attitudes to risk } X_{311}\end{array}$ & $\begin{array}{l}0.040 \\
0.037 \\
0.019 \\
0.035 \\
0.032 \\
0.037 \\
0.031 \\
0.035 \\
0.033 \\
0.042 \\
0.029 \\
\end{array}$ \\
\hline
\end{tabular}


Table 4. Characteristic values of second-class indexes of the He Qiang An (HQA) water source protection project risk assessment.

\begin{tabular}{|c|c|c|c|}
\hline & First-class index & Second-class index & $\begin{array}{c}\text { Second-class index } \\
\text { characteristic } \\
\text { values }\end{array}$ \\
\hline \multirow{12}{*}{$\begin{array}{l}0 \\
0 \\
.0 \\
0 \\
0 \\
0 \\
0 \\
0 \\
0 \\
0 \\
0 \\
0 \\
0 \\
0 \\
0 \\
0 \\
0 \\
0 \\
0 \\
0 \\
0 \\
0 \\
0 \\
0 \\
\pi \\
3\end{array}$} & \multirow{12}{*}{ Government risk $X_{1}$} & Government credit risk $X_{11}$ & 87.45 \\
\hline & & Risk of government intervention $X_{12}$ & 87.90 \\
\hline & & Risk of socialization $X_{13}$ & 74.21 \\
\hline & & Officials seeking rent risk $X_{14}$ & 89.21 \\
\hline & & Risk in government decision-making $X_{15}$ & 74.21 \\
\hline & & Government approval risk $X_{16}$ & 78.94 \\
\hline & & Legal changes risk $X_{17}$ & 67.89 \\
\hline & & Risk that legal and regulatory systems are not perfect $X_{18}$ & 73.34 \\
\hline & & Tax risk $X_{19}$ & 72.12 \\
\hline & & Exclusiveness risk $X_{110}$ & 77.36 \\
\hline & & Social capital partners bidding risk $X_{111}$ & 83.45 \\
\hline & & Payment risk $X_{112}$ & 78.21 \\
\hline$\overleftrightarrow{\sim}$ & & Market demand change risk $X_{21}$ & 65.21 \\
\hline$\stackrel{\wp}{9}$ & Market risk $X_{0}$ & Interest rate risk $X_{22}$ & 83.45 \\
\hline$\cong$ & Hathed Hon $\Lambda_{2}$ & Foreign exchange risk $X_{23}$ & 82.34 \\
\hline$\ddot{0}$ & & Inflation risk $X_{24}$ & 85.13 \\
\hline $\begin{array}{l}w_{n} \\
v_{2}^{2} \\
n_{2}\end{array}$ & & Social capital risk $X_{31}$ & 93.42 \\
\hline$\underset{0}{0}$ & & Environmental risk $X_{32}$ & 92.12 \\
\hline.$\nexists$ & & War risk $X_{33}$ & 53.21 \\
\hline$\stackrel{\Xi}{\Xi}$ & & Construction risk $X_{34}$ & 84.56 \\
\hline $\begin{array}{l}\vec{n}_{2} \\
v_{0}\end{array}$ & & Materials and equipment supply risk $X_{35}$ & 78.43 \\
\hline$\frac{0}{\tilde{\omega}}$ & Project risk $X_{3}$ & Operational risk $X_{36}$ & 89.32 \\
\hline$\frac{-4}{2}$ & & Environmental risk $X_{37}$ & 77.21 \\
\hline & & Project financial supervision risk $X_{38}$ & 84.35 \\
\hline & & Project subjective risk $X_{39}$ & 83.82 \\
\hline & & Project organization and coordination risk $X_{310}$ & 87.89 \\
\hline & & Public attitudes to risk $X_{311}$ & 87.21 \\
\hline
\end{tabular}

tection project. They obtained the risk assessment index via Eq. (1). The specific results are shown in Table 4;

Step 3. Calculating the correlation function value of every index of the HQA water source protection project. The correlation function value of every index of the HQA water source protection project is calculated by Eqs. (2)-(4). The specific results are shown in Table 5;

Step 4. Calculation of all types of risk on the level of correlation and rating of the HQA water source protection project. The correlation degree of all types of risk in all class types of the HQA water source protection project and rating is calculated via Eq. (5).
The correlation degree of all types of risk in all class types of the HQA water source protection project and rating is shown below (see Table 6 ).

\subsection{Conclusion of the risk assessment of the $H Q A$ water source protection project}

From Table 6 , we can see that the government risk, market risk, and project risk facing the project are all associated with the fifth class (the highest class). In addition, the overall risk assessment of the HQA water source protection project is also associated with the fifth class (the highest class). That is to say, sound project implementation and social capital should be used to strengthen the risk management in the implementation of the project, thus ensuring the smooth 
Table 5. Correlation function value of every index of the He Qiang An (HQA) water source protection project.

\begin{tabular}{|c|c|c|c|c|c|c|}
\hline Second-class index & $\begin{array}{l}\text { Second-class index } \\
\text { characteristic values }\end{array}$ & $j=1$ & $j=2$ & $j=3$ & $j=4$ & $j=5$ \\
\hline Government credit risk $X_{11}$ & 87.45 & -0.843 & -0.791 & -0.686 & -0.373 & 1.461 \\
\hline Risk of government intervention $X_{12}$ & 87.90 & -0.849 & -0.798 & -0.698 & -0.395 & 1.881 \\
\hline Risk of socialization $X_{13}$ & 74.21 & -0.678 & -0.570 & -0.355 & 0.290 & -0.183 \\
\hline Officials seeking rent risk $X_{14}$ & 89.21 & -0.865 & -0.820 & -0.730 & -0.461 & 5.829 \\
\hline Risk in government decision-making $X_{15}$ & 74.21 & -0.678 & -0.570 & -0.355 & 0.290 & -0.183 \\
\hline Government approval risk $X_{16}$ & 78.94 & -0.737 & -0.649 & -0.474 & 0.053 & -0.048 \\
\hline Legal changes risk $X_{17}$ & 67.89 & -0.599 & -0.465 & -0.197 & 0.326 & -0.274 \\
\hline Risk that legal and regulatory systems are not perfect $X_{18}$ & 73.34 & -0.667 & -0.556 & -0.334 & 0.333 & -0.200 \\
\hline Tax risk $X_{19}$ & 72.12 & -0.652 & -0.535 & -0.303 & 0.394 & -0.220 \\
\hline Exclusiveness risk $X_{110}$ & 77.36 & -0.717 & -0.623 & -0.434 & 0.132 & -0.104 \\
\hline Social capital partners bidding risk $X_{111}$ & 83.45 & -0.793 & -0.724 & -0.586 & -0.173 & 0.263 \\
\hline Payment risk $X_{112}$ & 78.21 & -0.728 & -0.637 & -0.455 & 0.090 & -0.076 \\
\hline Market demand change risk $X_{21}$ & 65.21 & -0.565 & -0.420 & -0.130 & 0.176 & -0.298 \\
\hline Interest rate risk $X_{22}$ & 83.45 & -0.793 & -0.724 & -0.586 & -0.173 & 0.263 \\
\hline Foreign exchange risk $X_{23}$ & 82.34 & -0.779 & -0.706 & -0.559 & -0.117 & 0.153 \\
\hline Inflation risk $X_{24}$ & 85.13 & -0.814 & -0.752 & -0.628 & -0.257 & 0.527 \\
\hline Social capital risk $X_{31}$ & 93.42 & -0.918 & -0.890 & -0.836 & -0.671 & 5.580 \\
\hline Environmental risk $X_{32}$ & 92.12 & -0.902 & -0.869 & -0.803 & -0.606 & 6.880 \\
\hline War risk $X_{33}$ & 53.21 & -0.415 & -0.220 & 0.170 & -0.127 & -0.364 \\
\hline Construction risk $X_{34}$ & 84.56 & -0.807 & -0.743 & -0.614 & -0.228 & 0.419 \\
\hline Materials and equipment supply risk $X_{35}$ & 78.43 & -0.730 & -0.641 & -0.461 & 0.078 & -0.068 \\
\hline Operational risk $X_{36}$ & 89.32 & -0.867 & -0.822 & -0.733 & -0.466 & 6.853 \\
\hline Environmental risk $X_{37}$ & 77.21 & -0.715 & -0.620 & -0.430 & 0.140 & -0.109 \\
\hline Project financial supervision risk $X_{38}$ & 84.35 & -0.804 & -0.739 & -0.609 & -0.218 & 0.385 \\
\hline Project subjective risk $X_{39}$ & 83.82 & -0.798 & -0.730 & -0.596 & -0.191 & 0.309 \\
\hline Project organization and coordination risk $X_{310}$ & 87.89 & -0.849 & -0.798 & -0.697 & -0.395 & 1.870 \\
\hline Public attitudes to risk $X_{311}$ & 87.21 & -0.840 & -0.787 & -0.680 & -0.361 & 1.292 \\
\hline
\end{tabular}

Table 6. Calculation of all types of risk of the He Qiang An (HQA) water source protection project.

\begin{tabular}{lccccccc}
\hline \multicolumn{1}{c}{$\boldsymbol{K}_{\boldsymbol{j}}(\boldsymbol{p})$} & First-class & Second-class & Third-class & Fourth-class & Fifth-class & Max & $\boldsymbol{j}_{\mathbf{0}}$ \\
\hline Government risk & -0.333 & -0.294 & -0.216 & 0.012 & 0.339 & 0.339 & 5 \\
Market risk & -0.126 & -0.110 & -0.077 & -0.012 & 0.024 & 0.024 & 5 \\
Project risk & -0.298 & -0.274 & -0.227 & -0.111 & 0.873 & 0.873 & 5 \\
Overall risk assessment & -0.758 & -0.678 & -0.519 & -0.112 & 1.236 & 1.236 & 5 \\
\hline
\end{tabular}

implementation of the project by the formulation of a risk response strategy and risk sharing.

\section{Conclusion}

This study analyzed and discussed the risk management problems existing in the process of PublicPrivate-Partnership (PPP) project implementation. Conducting identification of PPP project risk by using a decomposition analysis method and based on the scientific, system, comparison, and operation principles, it was found that PPP project risks included government risk, market risk, and project risk. Based on these findings, a constructed list of PPP project risks was established. Based on the analysis of the limitations of the traditional matter element model, the evaluation model of PPP project risk assessment of the improved matter element model was constructed 
in order to provide effective support for effective PPP project risk management, contract management, and other work.

As China's economy has entered into the "New Normal", for a period of time, the Chinese government will continue to promote the PPP model to ease financial pressure and improve the efficiency of government management. Therefore, it is extremely important to ensure that the risk management is standardized and practicable. This study established a risk assessment system; however, because the risk assessment index system contains too many qualitative indexes, the result of risk assessment can be easily influenced by subjective intentions. Therefore, the direction of future research should be toward the construction of a risk assessment index system that contains more quantitative indexes, which can clearly reflect the risks that the PPP projects faced.

\section{Acknowledgment}

This work is supported by the National Natural Science Foundation of China (\# Project No. 71801130), Science and Technology Project Plan of Ministry of Housing and Urban Rural Development-Soft Science Research Project (\# Project 2018-R4-003), Jiangsu Social Science Foundation Project (\# Project 18GLD013).

\section{References}

1. Zheng N.M., Zhang, Z.L., and Yan, L. "Study on life-cycle risk management of high earth-rock dam project", Eng. Sci., 5, pp. 45-50 (2013).

2. Teller, J. and Kock, A. "An empirical investigation on how portfolio risk management influences project portfolio success", Int. J. Project Manag., 31(6), pp. 817-829 (2013).

3. Marcelino-Sádaba, S., Pérez-Ezcurdia, A., Echeverría Lazcano, A.M., and Villanueva, P. "Project risk management methodology for small firms", Int. J. Project Manag., 32(2), pp. 327-340 (2014).

4. Irimia-Diéguez, A.I., Sanchez-Cazorla, A., and AlfallaLuque, R. "Risk management in megaprojects", Procardia - Soc. and Behav Sci., 119, pp. 407-416 (2014).

5. Hwang, B.G., Zhao, X.B., and Li, P. "Risk management in small construction projects in Singapore: Status, barriers and impact", Int. J. Project Manag., 32(1), pp. 116-124 (2014).

6. Yang, C.C. and Yeh, C.H. "Application of system dynamics in environmental risk management of project management for external stakeholders", Syst. Pract. Action Res., 27(3), pp. 211-225 (2014).

7. Nieto-Morote, A. and Ruz-Vila, F. "A fuzzy approach to construction project risk assessment", Int. J. Project Manag., 29(2), pp. 220-231 (2011).
8. Lee, E., Park, Y., and Shin, J.G. "Large engineering project risk management using a Bayesian belief network", Expert Syst. Appl., 36(3), pp. 5880-5887 (2009).

9. Song, J.B., Hu, Y.B., and Feng, Z. "Factors influencing early termination of PPP projects in China", J. Manage Eng., 34(1), pp. 05017008-1-05017008-10 (2018).

10. Ford, N. and Horioka, C. "The 'real' explanation of the PPP puzzle", Appl. Econ. Lett., 24(5), pp. 325328 (2016).

11. Abrera, J., Parham, A., and McDonough, J.F. "Publicprivate partnership, information technology, and operational efficiency at Sandy Springs, Georgia", IBM $J$. Res. Dev., 55(1-2), pp. 148-162 (2010).

12. Jianjun Zhu, Chew, D.A.S., Sainan, L.V., and Weiwei $\mathrm{Wu}$ "Optimization method for building envelope design to minimize carbon emissions of building operational energy consumption using orthogonal experimental design (OED)", Habitat Int., 37, pp. 148-154 (2013).

13. Liu, T., Bennon, M., Garvin, M.J., and Wang, S.Q. "Sharing the big risk: assessment framework for revenue risk sharing mechanisms in transportation public-private partnerships", J. Constr. Eng. M ASCE, 143(12), pp.04017086-1-04017086-12 (2017).

14. Wu, Y.N., Li, L.W.Y., Xu, R.H., Chen, K.F., Hu, Y., and Lin, X.S. "Risk assessment in straw-based power generation public-private partnership projects in China: A fuzzy synthetic evaluation analysis", $J$. Clean Prod., 161, pp. 977-990 (2017).

15. Xiong, W., Zhao, X.B., Yuan, J.F., and Luo, S. "Ex post risk management in public-private partnership infrastructure projects", Proj. Manag. J., 48(3), pp. 76-89 (2017).

16. Li, Y., Wang, X.Y., and Wang, Y.H. "Using bargaining game theory for risk allocation of public-private partnership projects: Insights from different alternating offer sequences of participants", J. Constr. M., 143(3) (2017).

17. Rivera, N.R. "Public-private partnerships in disaster risk reduction: The case of the chemical industry of coatzacoalcos, Mexico", Gest. Polit. Publica., 26(1), pp. $105-138$ (2017).

18. Carpintero, S. and Petersen, O.H. "Public-private partnerships (PPPs) in local services: risk-sharing and private delivery of water services in Spain", Local Gov. Stud., 42(6), pp. 958-979 (2016).

19. Taylor, B.M. and Harman, B. "Governing urban development for climate risk: What role for public-private partnerships", Envir. C, 34(5), pp. 927-944 (2016).

20. Ramezani, M., Kimiagari, A.M., and Karimi, B. "Interrelating physical and financial flows in a bi- 
objective closed-loop supply chain network problem with uncertainty", Sci. Iran., 22(3), pp. 1278-1293 (2015).

21. Chung, D. and Hensher, D.A. "Modelling risk perceptions of stakeholders in public-private partnership toll road contracts", Abacus, 51(3), pp. 437-483 (2015).

\section{Biographies}

Bo Liu is currently a lecture at the Department of Accounting in Nanjing Normal University, P.R. China.
His areas of research and interest are optimization in civil engineering problems, project financing, PublicPrivate Partnership (PPP) model and hydraulic engineering management.

Fu-Hua Sun is currently an Associate Professor of the Department of Accounting in Hohai University, Nanjing, P.R. China. Her areas of research and interest are project financing, Public-Private Partnership (PPP) model and resettlement management for water conservancy projects. 